\title{
PERIODICAL PRESS AS A SOURCE ON THE HISTORY OF GERMAN SETTLEMENTS IN THE VOLGA REGION IN THE 1920S (BASED ON THE MATERIALS OF THE NEWSPAPER "DIE WELT-POST")
}

\author{
Olga V. Erokhina (a) \& Ekaterina L. Furman (b) \\ (a) Moscow Pedagogical State University. Moskow, Russia. Email: ov.erokhina[at]mpgu.su \\ (b) Volgograd State University. Volgograd, Russia. Email: ekaterina.furman[at]volsu.ru
}

\begin{abstract}
The newspaper "Die Welt-Post" is analyzed in the article, namely, the rubric "Letters from Russia”, from 1920. It published correspondence of Volga Germans and their relatives who immigrated to America in the late 19th - early 20th centuries. The analyzed material allowed finding out how the Volga Germans perceived the economic and political situation in the country. Having survived the revolution, the Civil War like many peoples of the Soviet Russia, they experienced all the hardships of the economic policy pursued by the Bolsheviks. In the letters, they described the process of requisitions of food by food detachments in the villages and even told stories about their personal participation in the open confrontation with the authorities. With the first signs of famine in the Volga region, the Germans began to turn to relatives in America with requests to send food, clothing, money, or help to leave the country. However, there were also those who wanted to receive books, newspapers or magazines because they were in an information vacuum or wanted to develop intellectually. The Germans were very religious people and therefore they perceived the events that took place as tests sent from above. American aid had been perceived similarly. Often the Germans gave characteristics in an allegorical form using references to the Bible.
\end{abstract}

Keywords

Volga region; Germans; German colonists; American Relief administration; famine; new economic policy; Russia; America; F. A. Lorenz; "Die Welt-Post" newspaper

This work is licensed under a Creative Commons «Attribution» 4.0 International License 


\section{ПЕРИОДИЧЕСКАЯ ПЕЧАТЬ КАК ИСТОЧНИК ПО ИСТОРИИ НЕМЕЦКИХ ПОСЕЛЕНИЙ ПОВОЛЖЬЯ В 1920-Е ГОДЫ (ПО МАТЕРИАЛАМ ГАЗЕТЫ “DIE WELT-POST”)}

\section{Ерохина Ольга Викторовна (a), Фурман Екатерина Львовна (b)}

(а) Московский педагогический государственный университет. Москва. Россия. Email: ov.erokhina[at]mpgu.su

(b) Волгоградский государственный университет. Волгоград, Россия.

Email: ekaterina.furman[at]volsu.ru

\section{Аннотация}

В статье анализируется газета "Die Welt-Post", на страницах которой с 1920 г. появилась рубрика «Письма из России». В ней публиковалась корреспонденция поволжских немцев и их родственников, эмигрировавших в Америку в конце XIX - начале XX в. Проанализированный материал позволил выяснить, как поволжские немцы воспринимали экономическую и политическую ситуацию в стране. Они, как и многие народы Советской России, пережив революцию, Гражданскую войну, испытали на себе все тяжести проводимой большевиками экономической политики. В письмах ими описывался процесс реквизиций продотрядами продовольствия в селах, и даже приводились рассказы о личном участии в открытом противостоянии властям. С первыми признаками голода в Поволжье немцы стали обращаться к родственникам в Америку с просьбами прислать продовольствие, одежду, деньги или помочь выехать из страны. Однако были среди них и такие, которые хотели получать книги, газеты или журналы. Они находились в информационном вакууме или желали интеллектуально развиваться. Немцы были очень религиозными людьми и поэтому воспринимали происходившие события как испытания, посланные свыше. Точно так же ими воспринималась и американская помощь. При этом многие характеристики давались немцами в иносказательной форме с использованием ссылок на Библию.

\section{Ключевые слова}

Поволжье; немцы; немецкие колонисты; Американская администрация помощи; голод; новая экономическая политика; Россия; Америка; Ф.А. Лоренц; газета "Die Welt-Post"

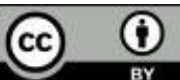

Это произведение доступно по лицензии Creative Commons «Attribution» («Атрибуция») 4.0 Всемирная 


\section{ВВЕДЕНИЕ}

Первая половина XX в. считается одним из самых сложных периодов российской истории, насыщенных бурными потрясениями. События, произошедшие в первой трети XX в., привели к коренным изменениям социально-экономических и политических устоев общества. При этом периодическая печать, обращенная советской властью в одно из мощнейших средств идеологического воздействия на население, призвана была не только формировать общественное мнение, транслируя определенные поведенческие стереотипы и установки, но и порой служила катализатором общественно-политических событий, наиболее яркие элементы которых отражала на своих страницах. Среди читательской аудитории газеты пользовались особым спросом в отличие от журналов, потому что в них предлагались материалы, разнообразные по жанру и темам. На их страницах наиболее оперативно публиковались сведения об общественно-значимых событиях, происходивших в стране и мире.

В СССР основными проводниками и пропагандистами новой власти выступали две центральные газеты «Правда» и «Известия», в которых рассказывалось об успехах советского государства. Издания следовали идеологической линии партии, отображая социальноэкономические и политические события в строгом соответствии с официально принятыми нормами, умалчивая зачастую о фактах, свидетельствовавших о негативных тенденциях в общественной жизни страны.

В своих мемуарах резидент английской разведки в Туркестане в 1918-1920 гг. подполковник Ф.М. Бейли так описывал советские газеты:

Авторы передовиц, по крайней мере, тех, которые читал я, ненавидели мою страну, и были при этом невежественными людьми, с крайне скудными знаниями истории и географии. Автор брал несколько фактов из устаревших книг, отбрасывал то, что не согласовывалось с его аргументами, искажал оставшиеся факты так, чтобы они согласовывались с его высказываниями, и добавлял несколько риторических выражений и лозунгов (Бейли, 2013, сс. 64-65).

Нельзя сказать, что газеты, издававшиеся за границей, были менее тенденциозными, чем советские. Периодическая печать не была объективной ни на Западе, ни в СССР, т.к. она выполняла определенный социальный заказ со стороны государства. Однако разнообразие информации в газетах делает их привлекательным историче- 
ским источником, позволяющим составить представление о социально-экономических отношениях в обществе или становлении господствующей идеологии в государстве.

В Советской России полным ходом шло строительство нового социалистического строя. Поэтому необходимо было показать все его преимущества перед капиталистическим, не оголяя действительного положения в стране, особенно в первые десятилетия советской власти. Венгерский революционный деятель М. Залки, работавший в то время в СССР, писал:

«Газеты фальшивы. Все сваливают на заграницу. Ложь «Правды» это страшно. Наш рубль стоит 1 коп. Это не кризис, хуже. Мы боимся говорить правду. Никто не смеет начать первым» (1988).

\section{ГA3ETA “DIE WELT-POST”}

Информацию о жизни в Советской России публиковали на своих страницах и иностранные газеты. Это могли быть репортажи собственных корреспондентов газет, материалы других агентств, интервью или письма читателей. В США издавалось несколько газет на немецком языке, игравших важную роль в жизни иммигрантов "Arbeiter-Zeitung", "Ostfriesische Nachrichten", "Der Staats Anzeiger", "Der Volksfreund". Они размещали на своих страницах актуальную политическую и социально-экономическую информацию об американском образе жизни. Обращали внимание на необходимость получение гражданства и даже размещали инструкцию, как правильно заполнить заявление. Редакторы газет призывали родителей отправлять своих детей в школу, указывая, как образование может помочь их детям найти в будущем лучшую работу.

Одной из самых популярных немецкоязычных газет можно по праву считать “Die Welt-Post”. В газете печатались новости о немцах и их поселениях на территории России в целом, но большая часть материала была посвящена населению и территориям бывших немецких колоний Поволжья. Корреспонденция личного характера становилась, зачастую, единственной возможностью узнать о реальном положении в них.

Газета была основана 16 апреля 1916 г. предпринимателями из Линкольна (штат Небраска), эмигрировавшими из поволжских немецких колоний. Они хотели собрать воедино информацию о массовом перемещении немцев-эмигрантов из России, а также получать и публиковать новости со своей бывшей родины. 
Первыми сотрудниками газеты стали Д. Д. Строх, К. Брем, Д. Д. Лебсак, Х. П. Векессер, А. Лебсак, Ф. А. Лоренц. Первые три выпуска были напечатаны в Хиллсборо, штат Канзас. Осенью, закупив наборные и печатные машинки, смогли открыть типографию в Линкольне, штат Небраска. Первыми редакторами газеты были Ф. А. Лоренц, родом из немецких колонистов Поволжья, и Г. Ф. Бешорнер.

В конце 1918 г. владельцы газеты «Die Welt-Post» продали eе В. Д. Петерсу, который владел несколькими немецкоязычными газетами в Омахе, штат Небраска. Редакторами газеты стали Г. Ян и позднее Э. Шульц. Больший объем публикаций, посвящаемых новой редакцией Германии (O.E, E.Ф. - родине Яна и Шульца), в ущерб информации о немецких колониях в России, привел к многочисленным жалобам подписчиков и, как следствие, снижению спроса на нее.

В мае 1920 г. к радости подписчиков Ф. А. Лоренц вернулся в редакторское кресло. Он смог значительно увеличить тираж газеты, создав на следующий год рубрику «Briefe aus Rußland» («Письма из России»), в которой стали печататься письма друзей и родственников американской немецкой общины, оставшихся в Советской России. В Америке хотели знать, что происходило на их прежней родине после революционных событий 1917 г. и последовавшей Гражданской войны, коренным образом изменивших жизнь близких им людей. Идея Лоренца нашла горячий отклик среди подписчиков:

«Поскольку вы земляк из поволжских колоний, я полагаю, что вы постараетесь принести нам больше новостей со старой родины... Я по-прежнему надеюсь, что можно будет спокойно получать новости из поволжских колоний через «Die Welt-Post»... Мы надеемся, что Россия скоро начнет почтовое сообщение с Америкой, чтобы можно было получать и читать больше информации со старой родины, потому что, прежде всего, люди хотят знать, как обстоят дела в деревнях» (Geyer, 1920, 13 January, p. 5).

Голод, который переживали немецкие колонии Поволжья в начале 1920-х гг., стал одной из центральных тем газеты. Много внимания уделялось информации о гуманитарной помощи из Америки (хотя были и другие организации) через правительственную организацию Американская администрация помощи (APA “American Relief Administration”) (Аншакова, 2009).

Следует отметить, что газета не только публиковала статьи о голоде, но и сама активно оказывала помощь пострадавшим районам Поволжья и Юга России. Ф. А. Лоренц вложил немало усилий 
в организацию и работу Общества милосердия Центральных Штатов Поволжью, которое собрало более 100 тыс. долларов для покупки питания и одежды (Walker, 1968, p. 242).

В 1923 г. он лично отправился в поволжские колонии, чтобы убедиться в эффективности оказываемой помощи нуждающимся. К сожалению, из-за сильной простуды и перенапряжения у него развилась пневмония, приведшая к смерти. Он был похоронен в своей родной поволжской колонии Альт-Мессер.

Газета "Die Welt-Post" на своих страницах последовательно отстаивала принцип лояльности Соединенным Штатам - «Америка прежде всего». Она была одной из немногих, издававшихся на немецком языке и не печатавшей английский перевод новостей даже во время Второй мировой войны. В настоящее время газета очень востребована исследователями, которые занимаются изучением истории поволжских немцев.

B 1970 г. "Die Welt-Post" объединилась с другими немецкоязычными газетами под названием "Die Welt-Post und der Staats-Anzeiger". Постепенно интерес к немецким газетам угасал, вместе со смертью последних переселенцев, помнивших жизнь в России и немецкие колонии. Причиной закрытия газет чаще всего становились финансовые трудности. Газета "Die Welt-Post” прекратила работу 18 сентября 1970 г.

Статьи из газеты микрофильмированы и хранятся в Американском историческом обществе немцев из России (AHSGR) в Линкольне, штат Небраска. Газетные статьи были проиндексированы С.Д. Синнером в его брошюре "Letters from Hell" («Письма из ада»), опубликованной AHSGR в 2000 г..

\section{ПОВОЛЖСКИЕ НЕМЦЫ}

На этапе формирования автономной области немцев Поволжья в соответствии с декретом 19 октября 1918 г. в её состав были включены три новообразованных уезда Саратовской губернии - Голокарамышский, Екатериненштадтский, Ровенский, часть из которых в свое время входила в состав Новоузенского уезда Самарской губернии. Представление о зажиточных немецких колонистах предопределило и отношение советской власти к автономной области в условиях гражданской войны, когда успех в противостоянии с противником во многом определялся бесперебойным продовольственным снабжением армии и тыла. 
Антирыночная программа большевиков привела к массовому сокращению аграрного производства. С 1917 г. по 1920 г. в Области немцев Поволжья рожь составляла 26,3\%, а пшеница от 60,6 до 86,9\% посевных площадей. После 1921 г. посевные площади под пшеницей сократились до 14,9\% за счет посевов ржи (Фурман, 2011, с. 106). В Области немцев Поволжья поголовье скота уменьшилось в 5,5 раз, объем валовой продукции сельского хозяйства снизился в 6,5 раз (Герман, 2007, с. 17).

Кроме проведения насильственной заготовительной компании власть пыталась привлечь крестьянство к добровольной сдаче сельскохозяйственной продукции, установив на нее твердые цены. Однако крестьяне не хотели сдавать свою продукцию практически даром, предпочитая продавать ее на рынке или перекупщикам. Например, в Самарской губернии в 1918 г. твердая цена на пшеницу составляла 8 руб., на сельском рынке за нее давали 30-60 руб., а на городском 900-1300 руб. (Тишкина, 2008, с. 92).

Ситуация с продовольствием в Поволжье все более усугублялась. Мало того, что колонии пострадали от противостояния большевиков и казаков летом 1919 г., - на следующий год их земли были охвачены неурожаем. В ноябре 1920 г. Б. Спомер писал своим детям в Америку:

«К сожалению, о последнем урожае я не могу написать ничего хорошего. Он был очень беден. Что касается того, как сейчас обстоят дела с населением, то уже много людей осталось без хлеба и мало надежды на помощь» (Spomer, 1921, Februar 17, p. 5).

У людей отнимали то немногое, что у них было: «русские деньги ничего не стоят, а цены на все так высоки, что едва веришь, когда их слышишь» (Die Welt-Post, 1921, Februar 7, p. 7). Дефицит продовольствия способствовал росту цен более чем в 200 раз. Зачастую людям приходилось от отчаяния обменивать свою «последнюю одежду на тыкву и картофель, чтобы утолить голод» (Wuertz, 1921, December 15, p. 7). Немцы из колонии Бальцер писали родственникам в Америку:

«Ржаная мука стоит 180-200 тыс. рублей за пуд, белый хлеб или печенье, как их здесь называют, мы так давно не видели, что уже не помним, какие они на вкус. Картофель стоит от 30 до 40000 рублей за пуд. Вы можете себе представить, как нам приходится жить... Мясо стоит 3000 рублей, а рис - 8000 рублей за фунт. Мы ведем плачевное существование» (Jackel, 1921, December 15, p. 7)

В связи с нежеланием крестьянства добровольно сдавать государству продовольствие, большевиками было принято решение начать 
более наступление на деревню. Для этого чаще всего привлекались продотряды из других губерний. В Области немцев Поволжья хлебозаготовками занимался продовольственный отряд из Тулы.

Учитель из Шербаковки Александр Шик писал, что отряд забирал все: сначала деньги, потом фрукты, мясо, муку, лошадей, крупный рогатый скот, овец, свиней, кур, а также последнюю одежду. Тех, кто отказывался отдавать, расстреливали. Только в Щербаковке было расстреляно 42 человека. Вся Россия теперь «гнездо убийц» (Schick, 1921, December 22, p. 5).

Сигналом к началу проведения репрессивных действий в отношении немецкого крестьянства послужила телеграмма особоуполномоченного наркомата продовольствия в регионе А. Смирнова от 19 декабря 1919 г.:

Условия текущей хлебной кампании совершенно определенно выяснили, что сборка хлеба путем самотека, товарообмена совершенно неосуществима. Хлеб дает только организация систематического нажима на деревню, проведенная до самых низов... [в] случае невыполнения разверстки, халатности немедленно арестуется сельсовет или волсовет, передавая коммунистов партийному суду, беспартийных - Чека. Одновременно производятся поголовные реквизиции продуктов [в] размере всех ста процентов разверстки без учета каких-либо остатков [по] нормам. [В] случае же сознательного сокрытия излишков наряду [c] продуктами конфискуются весь скот, лошади. [О] принятых в этом порядке мерах, [a] равно фамилии арестованных возможно шире публикуются, сообщается губкому, уисполкому. Обычно двух-трех случаев таких конфискаций бывает достаточно, чтобы двинуть ссыпку (Герман, 2007, сc. 14-15).

Следует отметить, что нормы взимаемых продуктов с русских и немецких деревень сильно отличались. Например, осенью 1920 г. жителей поселения Франк Бальцеровского уезда Области немцев Поволжья обязали сдать 93 тыс. пуд. хлеба, а их соседей из Александровки Аткарского уезда Саратовской губернии всего 3 тыс. пуд. При этом численность жителей и наличие земли у них было одинаковым - 5 тыс. человек и 5,5 тыс. дес. земли (Герман, 2007, с. 15). Действия властей вызывали негативное отношение к ней и приводили к организации отрядов сопротивления.

Одним из очагов сопротивления было село Бальцер Карамышского района, в котором учитель Ф. Зальцман организовал полк добровольцев для борьбы против большевиков, но из-за отсутствия тяжелого вооружения и боеприпасов он был уничтожен. Организатор бежал в Астрахань, потом прятался в Саратове, пока родственники 
не помогли ему с документами. Оттуда он перебрался в Ригу, где стал директором школы, состоящей из 450 учеников, 13 классов и 18 учителей. Его зарплата составляла всего 2 тыс. руб. / мес. (15 долл. США), которых хватало только на еду. Однако «несмотря на все это, - писал он, - мы все равно живем здесь лучше, чем в России. Как люди там могут существовать, для меня загадка» (Salzmann, 1920, November 11, p. 2).

Немецкая интеллигенция имела представление о политической ситуации в стране, и не все ее представители положительно относились к захвату власти большевиками. Они считали, что передача власти в руки рабочих, которые ничего не понимают в управлении правительством, - безумие.

Из рабочего класса возникли организации под названием «Советы», которые немедленно привели к потере всякого желания работать. Образованные члены общества, которые хоть что-то понимали в управлении, были либо интернированы, либо казнены. Рабочий класс не работал и в основном даже не думал о работе. В результате страна стала настолько бедной, что люди умирали сотнями (Salzmann, 1920, November 11, p. 2).

В. А. Поляков, проанализировав климатические условия в Поволжье за 1920/1923-е гг. по трем показателям (температуре, количеству осадков и дождливых дней), пришел к выводу, что 1921 г. был более благоприятным для сельского хозяйства, чем предшествующий. Именно в 1920 г. были заложены основные причины голода, заключавшиеся в характере деятельности людей и нехватке зерна для посева, засухе и «взыскании непомерной разверстки в 10 млн. пудов» (Поляков, 2007a, с. 18; 2007b, сс. 295-296).

Неплохой урожай технических культур на короткое время позволял заменить хлеб. Люди радовались, если удавалось выпекать хлеб, в котором в равных пропорциях смешивалась мука с тыквой, экономя, таким образом, муку. Однако все чаще приходилось есть такие продукты, которые раньше люди никогда не стали бы есть; но «тот, кто не хочет умереть с голоду, должен иметь хорошее воображение» (Schnell, 1921, December 27, p. 5). Уже осенью стали понемногу забивать скот, который еще оставался.

В феврале 1921 г. были получены первые сообщения из Самарской губернии о смерти людей от голода. Но власти предпочитали в газетах об этом «говорить менее откровенно», чем на заседаниях ЦК РКП(б) (Ленин, 1970, с. 34)

Когда в некоторых селениях питания почти не осталось, люди стали искать помощи у своих немецких родственников, друзей и 
знакомых в других поселениях, где урожай, по их мнению, был лучше. Они везли повозки, нагруженные разными вещами и сельскохозяйственным оборудованием, чтобы обменять их на еду. В некоторых поселениях это можно было сделать через лавки. Но зачастую получали «всего 2-4 пуда фруктов, что было равносильно тому, чтобы опустить каплю воды в море». Людей охватывал страх, и они пытались уехать с насиженных мест, продавая фактически за бесценок дома, усадьбы и все, что у них оставалось.

...Они пустились в путь, который больше походил на попытку побега. Куда? Никто не знал, что сказать. - Только прочь, прочь, - кричали они, чтобы мы не умерли с голоду! - Эти Бедняги! Они хотели убежать от смерти и шли прямо в ее холодные объятия (Döll, 1921, Februar 27, p. 6).

Они стремились уехать туда, где, по их мнению, ситуация с продовольствием или условия жизни были значительно лучше. Одни стремились к родственникам в другой уезд, вторые на Кавказ или в Среднюю Азию, а третьи - уехать из России в Германию или Америку.

Учитель колонии Галка А. Шик писал, что ему с шестью детьми пришлось 11 недель добираться до польской границы на повозке, а там удалось сесть на поезд до Берлина. Он с тоской вспоминал свою жизнь в России, где кроме преподавательской деятельности занимался выращиванием винограда, но «теперь все осталось позади, и с глубокой меланхолией и страхом смотрю в будущее» (Schick, 1921, December 22, p. 5). Попытки уехать за границу не всегда оказывались удачными. Многие вынуждены были вернуться после того, как израсходовали все свои деньги, ожидая на границе разрешения на выезд из России (Strauch, 1922, February 2, p. 2).

Специально для меннонитов Русско-Канадско-Американское пассажирское агентство (РусКАПА) предоставляло кредит на проезд до Канады. Для этого составлялись списки желающих выехать, с указанием возраста и состава семьи. Но для получения кредита необходимо было принадлежать к меннонитской общине, иметь заграничный паспорт, справки о здоровье и отсутствии препятствий к выезду за границу, а также предоставить удостоверение о занятии земледелием (ГАРФ, 1927, л. 3-3об). Однако даже эти документы не гарантировали возможность выезда, т.к. в последний момент власти могли вычеркнуть из списков наиболее обеспеченных, по их мнению, меннонитов (ГАРФ, 1925, л. 28).

Страх и осознание неизбежной смерти от голода заставлял немцев обращаться с просьбами к родственникам или друзьям, 
живущим в Америке. Люди писали письма с мольбой о помощи деньгами, одеждой, продовольствием или билетом до Америки: «Если вы можете, то поддержите нас в нашем тяжелом положении. Мы находим надежду и утешение в словах этой песни:

Gott wird's machen, dass die Sachen Gehen, wie es Heilsam ist, Lasst die Wellen immer Schwellen, Wenn Dir nur bei Jesu bist!» (Köhler, 1921, September 27, p. 5).

Очень часто при описании своего положения они использовали сравнения с библейскими сюжетами: «В настоящее время мы находимся во времена Иеремии 15:2-3, Иезекииля 14:21, и третьей книги Моисея 26:26» (Hill, 1921, August 25, p. 5).

Ощущался и крайний дефицит литературы на родном языке. Сельская интеллигенция, если и могла позволить себе приобретать литературу, то все чаще с оплатой в рассрочку. Книжные же магазины требовали внесения предоплаты. Любителей читать угнетало это обстоятельство, потому что они «не могли удовлетворить свои интеллектуальные потребности» и «идти в ногу с научным прогрессом», особенно в деревнях. Им приходилось уныло констатировать, что дела ухудшаются, а «они... без интеллектуальной подпитки, становились старше и скучнее» (Seidlitz, 1924, June 12, p. 3).

Им хотелось выбраться из информационного вакуума: «Человек чувствует себя таким одиноким, он жаждет новостей из Америки и других стран. Если возможно, пришлите нам американскую газету» (Kluck, 1921, April 11, p. 8). Однако редакция с сожалением отмечала, что не может этого сделать из-за отсутствия прямого почтового контакта с Россией. С 1922 г. такая возможность появится.

Некоторые были готовы подписаться на немецкоязычные газеты или журналы, но возможности их получения были ничтожны: «Мои хорошие друзья заказали для меня несколько газет, но ни один номер не попал мне в руки». Конечно, для общения оставалась еще переписка, но письма не могли заменить периодические издания, т.к. в редакциях «знали больше... о том, что произошло и что делается в каждой стране» (Kromm, part 5, 1923, July 5, p. 3).

К тому же из-за дороговизны марок, конвертов и бумаги немцы вынуждены были их экономить на внутренней переписке, чтобы иметь возможность писать письма за границу. Корреспонденция в Америку стоила так дорого (7 млн. руб. против 10 коп. в прежние 
времена), что приходилось в одном письме вмещать обращения нескольких жителей (Seidlitz, 1924, May 24, p. 5).

Поэтому часто в письмах встречались такие строчки: «В Америке вы знаете гораздо больше, у вас каждый день есть новости отовсюду, в то время как я сижу без газет, если только случайно не увижу их где-нибудь» (Kromm, 1923, July 5, p. 3). Якоб Бауэр просил брата, жившего в Йорке, штат Небраска, присылать ему газету «Die WeltPost», a в ответ он обещал отправлять отчеты для публикаций (Bauer, 1923, September 27, p. 8).

В газету также писали и те немцы, которые приехали в Россию после революции 1917 г. из-за границы в надежде на перемены к лучшему в своей деревне, но через несколько лет выражавшие желание вернуться назад. В 1921 г. они вынуждены были констатировать: «цены так сильно выросли, что выжить уже невозможно». При этом денег в России много, а ценности они никакой не представляли. «Для нас здесь, в России, все зашло слишком далеко» - писал Я. Дайнес. Через газету он просил американских немцев не только помочь ему с возвращением, но и написать своим друзьям в Поволжье, а еще лучше «помочь им с едой, иначе они умрут с голода» (Deines, 1921, December 29, p. 5).

На мольбу о помощи откликнулись многие американцы, которые стали перечислять в помощь нуждающимся Поволжья различные суммы денег от 2 до 1000 долл. США. Только с 9 ноября по 1 декабря 1921 г. газетой «Die Welt-Post» были собраны и отправлены в Россию пожертвования в размере 5244,43 долл. США (Wagner, 1921, December 22, p. 5).

Пастор Э. Эйхорн благодарил американцев за помощь, которую они оказывали жителям пострадавших районов, потому что весной «вся деревня (Аль-Мессер - О.Е., Е.Ф.) превратилась бы в большое поле трупов». Он очень переживал за детей, одетых в лучшем случае лохмотья, выглядевших бледными и грязными. С тревогой думал об их будущем, так как они не получали должного образования, религиозного воспитания и необходимых детских услуг. В письме пастору Л. Золхеру, жившему в Портланде, им с горечью отмечалось:

...мы проповедуем только пустым скамьям, удерживая пустые недовольные сердца людей. И мы сами служим, вся наша надежда и желание исчезли, вся наша радость исчезла.... обратитесь к своим собратьямпасторам и вытащите нас из нашего разорения и упадка. Не хватает одежды и одеяний для служителей, приближается весна, и мы не знаем, чем будем прикрываться (Eichhorn, 1922, April 6, p. 2). 
Большинство родителей не знали, как и чем будут кормить своих детей. Поэтому их могли оставлять в детских домах в надежде, что там они точно будут накормлены. Когда начала работу $\mathrm{APA}^{1}$, то появилась возможность накормить хотя бы часть детей и взрослых: «Избитые и раздавленные голодом и чрезвычайным положением, с каждым кормлением они становились все веселее, все живее» (Paul, 1922, June 5, р. 5). Жители немецких поселений отмечали, что были и такие случаи, когда в некоторых семьях не голодали, но они предпочитали отправлять своих детей на американские кухни, пользуясь тем, что едой кормили всех детей до 15 лет $^{2}$.

Ha страницах газеты «Die Welt-Post» публиковались статьи о работе этой организации в России или письма-отчеты от тех, кто принимал непосредственное участие в оказании помощи. Кроме того, разворачивалась полемика между теми, кто посылал помощь, и теми, кто ее получал.

Американцы хотели оказывать помощь конкретным людям или селениям, а также требовали, чтобы помощь распределялась поровну между жителями. Однако поволжские немцы считали, что неправильно диктовать им, кому и сколько раздавать одежды и продовольствия. Они обращали внимание на то, что сделать пожертвование гораздо легче, чем распределить его среди масс. Зная истинное положение нуждающихся изнутри, они вносили свои коррективы:

Если бы вы были здесь и могли видеть то, что мы видим каждый день, вы бы поняли факты и сказали: дайте Ханнесу, который без рубашки и не может выйти на улицу, когда идет снег, чтобы он мог пойти в церковь большую долю, чем Филиппу, у которого все еще есть 2 смены одежды (Schlotthauer, 1923, May 31, p. 2-3).

В августе 1921 г. АРА под руководством Г. Гувера обязалась накормить 1 млн. русских детей, но столкнулась с непредвиденными трудностями и вынуждена была начать свою работу только в 1922 г. Американцами были созданы кухни, на которые поставлялось продовольствие, кормившие 1,2 млн. детей, и их численность постоянно увеличивалась. Например, в марте 1922 г. в Байдеке было открыто 2 кухни, где раз в день питалось 550 детей (Ostermiller, 1922, March 23, p. 5). Зимой 1923 г. советские власти обратились с просьбой накормить уже 3 млн. детей.

1 Помощь этой организации была не единственной. Голодающему Поволжью помогали: Международный союз помощи детям, германский Красный Крест, Коммунистический интернационал и другие.

2 По соглашению, заключенному между Россией и АРА 20 августа 1921 г., помощь могли получать дети в возрасте до 15 лет, признанные голодающими. 
Недоедание подрывало силы людей, и по всей стране начались эпидемии. Больницы оказались в безвыходном положении, т.к. им не хватало лекарств и бинтов. В одной больнице, в которой находились сотни пациентов, был только один термометр для измерения температуры. В другой больнице было вывешено объявление: «Пациенты, нуждающиеся в перевязке, должны предоставить свои собственные бинты» (Die Welt-Post, 1923, January 11, p. 2).

AРА выделила 3789076 долл. США на оборудование 11446 больниц и аналогичных учреждений. Для борьбы с холерой и другими эпидемиями было распределено 26,5 млн. доз вакцин и сыворотки. Всего до середины декабря 1922 г. было направлено в Россию медикаментов и продовольствия: 500 млн. ф. зерна, из которых 250 млн. ф. составляли пшеница, более 265 млн. ф. мука, более 265 млн. ф. гранулированного зерна, около 180 млн. ф. молока, 50 млн. ф. ржи, около 45 млн. ф. сахара и риса, 26 млн. ф. сала, 17 млн. ф. бобов и гороха, почти 8 млн. ф. какао и почти 13 млн. ф. лекарств (Die Welt-Post, 1923, January 11, p. 2).

Кроме продовольствия немцы часто писали, что «ситуация с одеждой также оставляет желать лучшего. Мы носим свою последнюю одежду на наших телах, и это всего лишь лохмотья» (Reit, 8 December, 1921, p. 5). В результате АРА стала закупать в США вещи и привозить их в Россию.

Через эту организацию многие американцы посылали посылки своим родственникам и знакомым. Среди поволжских немцев бытовало мнение, что это «самый безопасный способ отправить помощь» (Briefe aus Russland, 1922, April 20, p. 7). Однако очень частыми были случаи, когда посылки крали по дороге или вытаскивали из них часть вещей. Где это происходило, в Америке или России, установить не удалось. Обычно в их пропаже обвиняли людей, занимавшихся получением и распределением одежды.

По требованию советских властей, если человек получал индивидуальный пакет, он не мог участвовать в получении одежды из общего распределения, ее должны были передать только бедным. Для контроля за соблюдением этого распоряжения в селения направлялись представители правительства. В результате в Байдеке более 70 семей были лишены возможности получать что-либо из общего распределения. Такие действия властей вызывали в народе зависть и недовольство:

Богатые проклинают бедных, которые ничего не должны получать; ленивых, которые не работают, а только ждут, когда американцы оденут и накормят их. Бедные проклинают богатых, которые хотят все для себя и 
ничего не оставляют бедным... теперь, когда из Америки больше ничего не приходит, в деревнях стало тише, и зависть почти прекратилась (Pritscher, 1923, September 13, p. 5).

Продовольственная помощь со стороны благотворительных организаций и государства была жизненно необходима для голодающего населения. Но также радость у него вызывали поставки сельскохозяйственной техники и домашнего скота. Они говорили не "Wir Arbeiten" (мы работаем), a "Wir Schaffen” (мы создаем). Конечно, среди немецкого населения по-разному относились к оказываемой помощи. Некоторые считали, что товары и продовольствие лучше предоставлять не бесплатно, а в качестве займа. Потому что «подарки больше портят людей, чем помогают... легко удовлетвориться бесконечными подарками и, таким образом, стать полностью испорченными и ленивыми людьми» (Kromm, part 5-6, 1923, July 5, p. 3).

В конце 1922 г. председатель ВЦИК М.И. Калинин признавал, что «зарубежный капиталистический мир принес довольно солидную помощь, которая измеряется 3 десятками миллионов пудов в год. Я не сомневаюсь, товарищи, что помощь, которая принесена нам Западом, работа, которая произведена западноевропейскими и американскими представителями, пожалуй, лучшее, что сделано капиталистическим миром в последние годы» (Поляков, 2012, с. 188)

Немцы из Америки скучали по своим старым колониям и просили оставшихся в России писать не только о том, что происходит в стране, но и как выглядят их бывшие дома и местность. В результате они получали неприглядную картину:

... если бы теперь можно было заглянуть в хижины, то есть в несколько домов тех, кто имеет средние средства, что бы они там увидели? Они увидят: стойла, пустые от скота, шкафы без хлеба, перекрытия и доски с крыш, стропила крыши, каркас и доски пола, двери и окна, да, целые хозяйственные постройки с оградой, все исчезло, продано, а вырученные средства израсходованы (Donis, 1922, July 20, p. 3).

Незавидным стало и положение церкви в поселениях, «приходилось выслушивать больше религиозных богохульств от упрямых бессердечных людей» (Cammerzell, July 3, 1924, p. 5), особенно после того, как церковь и государство были разделены. В связи с этим церковный совет потерял авторитет среди части прихожан, не имея возможности наказывать или отдавать распоряжения жителям.

В каждой деревне имелся церковный совет, состоявший из 3-4 церковных старейшин и членов совета от 10 до 20 человек в зависимости от размера деревни. Однако для проведения молитвен- 


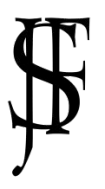

Журнал Фронтирных Исследований. 2021. No 4 | ISSN: 2500-0225

Историография и источники | Doi: https://doi.org/10.46539/jfs.v6i4.333

ного собрания с прихожанами требовалось получить разрешение властей, предварительно указав все вопросы, которые предполагалось обсуждать.

Пасторов беспокоило, что прихожане переставали заботиться о церкви (Wuertz, March 20, 1924, p. 3). Дело дошло до того, что «люди стали нецивилизованными из-за великой нищеты и голода, так что даже Пастору не оказывали уважения» (Donis, 1922, July 20, p. 3). Однако старики продолжали по-прежнему регулярно посещать церковь. Например, ни одной церковной службы в селе Гололобовка не пропустила пожилая пара Иоганн Генрих Шеллер, 79 лет, и его жена Катарина Элизабет, 79 лет рождения, которые находились в браке 60 лет (Wuertz, 1925, June 11, p. 5).

Постепенно жизнь налаживалась. О том, что ситуация с продовольствием улучшалась, свидетельствовало отсутствие умерших и попрошаек. Люди отмечали: «Дети снова весело играют на улицах, а взрослые, как и в прежние времена, занимаются своей работой ... мало-помалу жизнь возвращается в деревни» (Kromm, part 2, 1923, July 5, p. 3). О том, что у народа просыпался интерес к жизни, свидетельствовало и количество свадеб: в Кольбе и Франке женилось по 6 пар, а в Гуссенбахе 10 (Kluck, 1924, April 10, p. 2).

Немаловажную роль в стабилизации ситуации сыграли власти. Было принято решение о выделении части земли и урожая для поддержки бедных. Кроме того, были созданы Комиссии по делам бедноты, чтобы оказывать помощь тем семьям, которые в ней нуждались. «Наиболее нуждающимся помогали со всех сторон», чтобы они могли выжить. При этом те, кто еле-еле сводил концы с концами, при распределении продуктов говорили, что «бедные не беднее нас, и все же они получают все, а мы ничего». Первым не нужно было беспокоиться о сборах и налогах, в то время как у вторых их было много. Глядя на происходящее вокруг, учитель селения Бангердта Д. Кромм писал:

\footnotetext{
Чрезвычайная ситуация учит нас не только молиться, но и воровать, плохо отзываться о других и бог знает о чем еще. Я много раз удивлялся тому, как день ото дня росло воровство, и тем зверствам, которые, как я видел, были вызваны голодом. В то же время я также удивлялся тем, кто, несмотря на голод, грызущий их внутренности, спокойно терпел (Kromm, part 3, 1923, July 5, p. 3).
}

В письмах 1925 г. все чаще говорилось об улучшении жизни. В них встречались смешанные чувства: от радости крестьян от погоды и всходов озимых весной, в ожидании хорошего урожая, до тревоги из-за ветра, холода и продовольственного налога. Например, в отличие 
от предшествующих лет на полях Гололобовки (Alt Dönhof) удалось посеять 12000 пудов семян: пшеницу, ячмень, овес, просо и другие культуры. Большие надежды крестьяне возлагали на сельскохозяйственные кооперативы, организованные местными жителями. Они собирались заняться производством хлопчатобумажной ткани (сарпинки), обеспечив работой односельчан (Wuertz, 1925, June 11, p. 5).

Кроме продовольствия и одежды из Америки стали посылать еще и доллары. Крестьяне обменивали их в государственном банке и покупали необходимые товары. Например, Г. Вайденкеллер из Норки получил от родственников из Чарльстона банковский чек на 50 долларов, которые при обмене составили 11 млрд. 500 млн. рублей. Правда, эти деньги он должен был разделить с братом, четырьмя сестрами и детьми, оставшимися сиротами после смерти сестры Луизы (Weidenkeller, 1924, March 13, p. 5).

Люди старались не унывать и приспособиться к новым условиям жизни. Экономика постепенно восстанавливалась, хотя ощущалась нехватка одежды, скота и сельскохозяйственной техники. Торговля в городах начинала оживать, хотя частная торговля почти полностью исчезла, потому что «все торговое движение находилось в руках организаций, всевозможных ассоциаций, корпораций». Товары все еще были настолько дороги, что крестьянин с его ограниченными средствами почти ничего не мог купить. «Жизнь в нашей Республике сегодня по-прежнему тяжелая, но она улучшается день ото дня, писал Г. Думмлер, - люди получают все больше и больше рабочего скота и снова постепенно восстанавливаются» (Dummler, 1924, July 2, p. 5).

\section{ВЫВОДЫ}

Рассмотренные номера газеты «Die Welt-Post» свидетельствуют о том, что письма в ней публиковались изо всех селений Области немцев Поволжья. ${ }^{1}$ В них затрагивались совершенно разные проблемы, волновавшие немцев. Конечно, первоочередной была просьба о продовольственной помощи. Политика большевиков, проводившаяся с 1918 по 1921 г., привела сельское хозяйство поволжских немцев в состояние полного расстройства, которое довершилось неурожаем в 1921/22 гг.

В результате немцы вынуждены были продавать или менять мебель, сельскохозяйственную технику, одежду на продовольствие.

113 декабря 1923 г. Область немцев Поволжья была преобразована в Автономную Советскую Социалистическую Республику немцев Поволжья. 


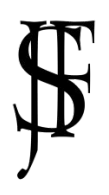

От голода они пытались выехать в другие губернии или за границу. Но не всем удавалось «убежать от смерти».

Они обратились за помощью к своим родственникам и друзьям, жившим в Америке. Благодаря их продовольственной поддержке, а также деятельности АРА, удалось спасти многие человеческие жизни. Были организованы кухни, и выдавались индивидуальные и общественные посылки.

Однако вслед за продовольственным голодом пришел холод. У людей фактически не осталось одежды, чтобы выходить на улицу и в церковь. И снова им помогли американские немцы, которые присылали вещи и обувь.

Но изученные письма показывают, что потребности людей не были ограничены только материальными ценностями. Они хотели получать и духовное развитие; поэтому очень часто просили прислать им книги, газеты или журналы. Люди продолжали посещать церкви и происходившие с ними события трактовали с опорой на Библию.

\section{Список литературы}

American Aid Saves Millions in Russia. (1923, January 11). Die Welt-Post, p. 2.

Bauer, J. (1923, September 27). Briefe aus Russland [Letters from Russia]. Die Welt-Post, p. 8. (In German).

Briefe aus Russland [Letters from Russia]. (1922, April 20). Die Welt-Post, p. 7. (In German).

Cammerzell, J., \& Cammerzell, J. (1924, July 3). Briefe aus Russland [Letters from Russia]. Die Welt-Post, p. 5. (In German).

Deines, J. (1921, December 29). Ein Brief von einem Russen, der zu vor in Amerika gelebt [A letter from a Russian who had lived in America before]. Die Welt-Post, p. 5. (In German).

Döll, A. (1991, February 27). Wiesenmiller. Die Welt-Post, p. 6. (In German).

Donis, J., \& Dreuth, J. (1922, July 20). Briefe aus Russland [Letters from Russia]. Die Welt-Post, p. 3. (In German).

Dummler, G. (1924, July 2). Briefe aus Russland [Letters from Russia]. Die Welt-Post, p. 5. (In German).

Eichhorn, E. (1922, April 6). Briefe aus Russland. Alt-Messer. Die Welt-Post, p. 2. (In German).

Geyer, G. (1920, January 13). Aus Südamerika [From South America]. Die Welt-Post, p. 5. (In German).

Hill, J. (1921, August 25). Briefe aus Russland [Letters from Russia]. Die Welt-Post, p. 5. (In German). 
Jackel, J. (1921, December 15). Briefe aus Russland [Letters from Russia]. Die Welt-Post, p. 7. (In German).

Kluck, A. (1924, April 10). Briefe aus Russland [Letters from Russia]. Die Welt-Post, p. 2. (In German).

Kluck, B. (1921, April 11). Briefe aus Russland. Walter-Khutor [Letters from Russia. Walter-Khutor]. Die Welt-Post, p. 8. (In German).

Köhler, K. (1921, September 27). Briefe aus Russland. Norka [Letters from Russia. Norka]. Die Welt-Post, p. 5. (In German).

Kromm, J. (1923, July 5). Brief vom Lehrer von der Wolga [Letter from the teacher from the Volga]. Die Welt-Post, p. 3. (In German).

Mut, F. (1921, February 7). Aus Russland: Interessanter Brief von Grimm, Saratow [From Russia: Interesting letter from Grimm, Saratov]. Die Welt-Post, p. 7. (In German).

Ostermiller, C. (1922, March 23). Aus Russland [From Russia]. Die Welt-Post, p. 5. (In German).

Paul, K., Hardt, F., \& Pauli, A. (1922, June 5). Schriftlicher Dank von Anton, Russland [Written thanks from Anton, Russia]. Die Welt-Post, p. 5. (In German).

Pritscher, E. (1923, September 13). Einfache "Wahrheit" über die Verteilung von Kleidung in Beydeck, Russland [Simple "truth" about the distribution of clothing in Beydeck, Russia]. Die Welt-Post, p. 5. (In German).

Reitz, J. (1921, December 8). Wichtiger Brief aus Russland [Important letter from Russia]. Die Welt-Post, p. 5. (In German).

Salzmann, F. (1920, November 11). Ein sehr wichtiger Brief aus Russland [A very important letter from Russia]. Die Welt-Post, p. 2. (In German).

Schick, A. (1921, December 22). Ein Hilferuf! [A call for help!]. Die Welt-Post, p. 5. (In German).

Schlotthauer, J. (1923, May 31). Briefe aus Russland [Letters from Russia]. Die Welt-Post, pp. 2-3. (In German).

Schnell, M. (1921, December 27). Herzzerreißende Nachrichten aus Russland [Heartbreaking news from Russia]. Die Welt-Post, p. 5. (In German).

Seidlitz, J. (1924a, May 24). Bericht an den Lutherischen Nationalrat [Report to the Lutheran National Council]. Die Welt-Post, p. 5. (In German).

Seidlitz, J. (1924b, June 12). Briefe aus Russland [Letters from Russia]. Die Welt-Post, p. 3. (In German).

Spomer, B. (1921, February 17). Briefe aus Beideck, Russland [Letters from Beideck, Russia]. Die Welt-Post, p. 5. (In German).

Strauch, J. (1922, February 2). Original Reportagen aus Russland [Original reports from Russia]. Die Welt-Post, p. 2. (In German).

Wagner, J. (1921, December 22). Für russische Hilfsarbeiten [For Russian auxiliary work]. Die Welt-Post, p. 5. (In German). 


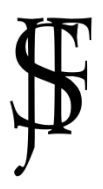

Журнал Фронтирных Исследований. 2021. No 4 | ISSN: 2500-0225

Историография и источники | Doi: https://doi.org/10.46539/jfs.v6i4.333

Walker, G. S. (1968). Die Welt-Post. (1916-1921) (Vol. 1). Lincoln.

Weidenkeller, G. H. (1924, March 13). Briefe aus Russland [Letters from Russia]. Die Welt-Post, p. 5. (In German).

Wuertz, C. (1921, December 15). Briefe aus Beideck, Russland [Letters from Beideck, Russia]. Die Welt-Post, p. 7. (In German).

Wuertz, C. (1924, March 20). Briefe aus Russland [Letters from Russia]. Die Welt-Post, p. 3. (In German).

Wuertz, A. (1925, June 11). Original Reportagen aus Russland [Original reports from Russia]. Die Welt-Post, p. 5. (In German).

Аншакова, Ю. Ю. (2009). Гуманитарная миссия АРА в Советской России: Начало взаимодействия. Известия Самарского научного центра Российской академии наук, 11(2), 50-72.

Бейли, Ф. М. (2013). Миссия в Ташкент. Москва: Языки славянской культуры.

Герман, А. А. (2017). Национально-территориальная автономия немцев Поволжья (к 100-летию со дня образования). Ежегодник международной ассоциащии исследователей истории и культуры российских немцев. Научный журнал, (3), 10-38.

Государственный архив Российской Федерации. (1925). Ф. A-423. On.1 Д. 36.

Государственный архив Российской Федерации. (1927). Ф. A-423. On.1 Д. 120.

Из дневников Матэ Залки. (1988, июль 24). Московские новости, (29).

Ленин, В. И. (1970). Заключительное слово по отчету ЦК РКП(б) 9 марта 1921 г.

В Полное собрание сочинений. Том 43 (сс. 34-51). Москва: Издательство политической литературы.

Поляков, В. А. (2007а). Голод в Поволжье: Первый опыт государственной помощи в 1921 году. Вестник Волгоградского государственного университета. Серия 4: История. Регионоведение. Международные отношения, (12), 18-32.

Поляков, В. А. (2007b). Голод в Поволжье, 1919-1925 г2.: Происхождение, особенности, последствия. Волгоград: Волгоградское научное издательство.

Поляков, В. А. (2012). Проблема голода - важный компонент научно-исторического осмысления «НЭПа», или рецензия в жанре «ретро» на кн.: Поляков, Ю. А. Переход к НЭПу и советское крестьянство. М.: Наука, 1967. 512 с. Вестник Волгоградского государственного университета, Серия 4: История. Регионоведение. Международные отношения, (1), 186-193.

Тишкина, А. В. (2008). Товары и цены в Советской России в 19171921 гг. (На материалах Среднего Поволжья). Известия Пензенского государственного педагогического университета Им. В.Г. Белинского, (10), 88-93.

Фурман, Е. Л. (2011). Кооперативное движение в немецких колониях Поволжья (1906 - начало 1930-х годов). Волгоград: Волгоградское издательство ВолГУ. 


\section{References}

Anshakova, Yu. Yu. (2009). The humanitarian mission of the ARA in Soviet Russia: the beginning of interaction. Proceedings of the Samara Scientific Center of the Russian Academy of Sciences, 11(2), 50-72. (In Russian).

American Aid Saves Millions in Russia. (1923, January 11). Die Welt-Post, p. 2.

Bailey, F. M. (2013). Mission to Tashkent. Moscow: Languages of Slavic Culture. (In Russian).

Bauer, J. (1923, September 27). Briefe aus Russland [Letters from Russia]. Die Welt-Post, p. 8. (In German).

Briefe aus Russland [Letters from Russia]. (1922, April 20). Die Welt-Post, p. 7. (In German).

Cammerzell, J., \& Cammerzell, J. (1924, July 3). Briefe aus Russland [Letters from Russia]. Die Welt-Post, p. 5. (In German).

Deines, J. (1921, December 29). Ein Brief von einem Russen, der zu vor in Amerika gelebt [A letter from a Russian who had lived in America before]. Die Welt-Post, p. 5. (In German).

Döll, A. (1991, February 27). Wiesenmiller. Die Welt-Post, p. 6. (In German).

Donis, J., \& Dreuth, J. (1922, July 20). Briefe aus Russland [Letters from Russia]. Die Welt-Post, p. 3. (In German).

Dummler, G. (1924, July 2). Briefe aus Russland [Letters from Russia]. Die Welt-Post, p. 5. (In German).

Eichhorn, E. (1922, April 6). Briefe aus Russland. Alt-Messer. [Letters from Russia]. Die Welt-Post, p. 2. (In German).

From the Diaries of Mate Zalka. (1988, July 24). Moscow News, (29). (In Russian).

Furman, E. L. (2011). Cooperative movement in the German colonies of the Volga region (1906-early 1930s). Volgograd: Volgograd State University Press. (In Russian).

Geyer, G. (1920, January 13). Aus Südamerika [From South America]. Die Welt-Post, p. 5. (In German).

Herman, A. A. (2017). National-territorial autonomy of the Volga Germans (on the 100th anniversary of their formation). Yearbook of the International Association of Researchers of History and Culture of Russian Germans. Scientific Fournal, (3), 10-38. (In Russian).

Hill, J. (1921, August 25). Briefe aus Russland [Letters from Russia]. Die Welt-Post, p. 5. (In German).

Jackel, J. (1921, December 15). Briefe aus Russland [Letters from Russia]. Die Welt-Post, p. 7. (In German).

Kluck, A. (1924, April 10). Briefe aus Russland [Letters from Russia]. Die Welt-Post, p. 2. (In German).

Kluck, B. (1921, April 11). Briefe aus Russland. Walter-Khutor [Letters from Russia. WalterKhutor]. Die Welt-Post, p. 8. (In German). 


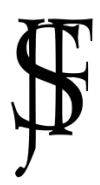

Журнал Фронтирных Исследований. 2021. No 4 | ISSN: 2500-0225

Историография и источники | Doi: https://doi.org/10.46539/jfs.v6i4.333

Köhler, K. (1921, September 27). Briefe aus Russland. Norka [Letters from Russia. Norka]. Die Welt-Post, p. 5. (In German).

Kromm, J. (1923, July 5). Brief vom Lehrer von der Wolga [Letter from the teacher from the Volga]. Die Welt-Post, p. 3. (In German).

Lenin, V. I. (1970). Final word on the report of the Central Committee of the RCP(b) on March 9, 1921. In The Complete Works. Volume 43 (pp. 34-51). Moscow: Publishing House of Political Literature. (In Russian).

Mut, F. (1921, February 7). Aus Russland: Interessanter Brief von Grimm, Saratow [From Russia: Interesting letter from Grimm, Saratov]. Die Welt-Post, p. 7. (In German).

Ostermiller, C. (1922, March 23). Aus Russland [From Russia]. Die Welt-Post, p. 5. (In German).

Paul, K., Hardt, F., \& Pauli, A. (1922, June 5). Schriftlicher Dank von Anton, Russland [Written thanks from Anton, Russia]. Die Welt-Post, p. 5. (In German).

Polyakov, V. A. (2007a). Famine in the Volga region: the first experience of state aid in 1921. Bulletin of Volgograd State University. Series 4: History. Regional Studies. International Relations, (12), 18-32. (In Russian).

Polyakov, V. A. (2007b). Famine in the Volga region, 1919-1925: origin, features, consequences. Volgograd: Volgograd Scientific Publishing House. (In Russian).

Polyakov, V. A. (2012). The problem of hunger is an important component of the scientific and historical understanding of the "NEP", or a review in the genre of "retro" in the book: Polyakov, Yu. A. Transition to the NEP and the Soviet peasantry. Moscow: Nauka, 1967. 512 p. Bulletin of Volgograd State University. Series 4: History. Regional Studies. International Relations, (1), 186-193. (In Russian).

Pritscher, E. (1923, September 13). Einfache "Wahrheit" über die Verteilung von Kleidung in Beydeck, Russland [Simple "truth" about the distribution of clothing in Beydeck, Russia]. Die Welt-Post, p. 5. (In German).

Reitz, J. (1921, December 8). Wichtiger Brief aus Russland [Important letter from Russia]. Die Welt-Post, p. 5. (In German).

Salzmann, F. (1920, November 11). Ein sehr wichtiger Brief aus Russland [A very important letter from Russia]. Die Welt-Post, p. 2. (In German).

Schick, A. (1921, December 22). Ein Hilferuf! [A call for help!]. Die Welt-Post, p. 5. (In German).

Schlotthauer, J. (1923, May 31). Briefe aus Russland [Letters from Russia]. Die Welt-Post, pp. 2-3. (In German).

Schnell, M. (1921, December 27). Herzzerreißende Nachrichten aus Russland [Heartbreaking news from Russia]. Die Welt-Post, p. 5. (In German).

Seidlitz, J. (1924a, May 24). Bericht an den Lutherischen Nationalrat [Report to the Lutheran National Council]. Die Welt-Post, p. 5. (In German).

Seidlitz, J. (1924b, June 12). Briefe aus Russland [Letters from Russia]. Die Welt-Post, p. 3. (In German). 
Spomer, B. (1921, February 17). Briefe aus Beideck, Russland [Letters from Beideck, Russia]. Die Welt-Post, p. 5. (In German).

State Archive of the Russian Federation. (1925). F. A-423. In.1 C. 36. (In Russian).

State Archive of the Russian Federation. (1927). F. A-423. In.1 C. 120. (In Russian).

Strauch, J. (1922, February 2). Original Reportagen aus Russland [Original reports from Russia]. Die Welt-Post, p. 2. (In German).

Tishkina, A. V. (2008). Goods and prices in Soviet Russia in 1917-1921. (based on the materials of the Middle Volga region). Proceedings of the Penza State Pedagogical University named after V.G. Belinsky, (10), 88-93. (In Russian).

Wagner, J. (1921, December 22). Für russische Hilfsarbeiten [For Russian auxiliary work]. Die Welt-Post, p. 5. (In German).

Walker, G. S. (1968). Die Welt Post. (1916-1921) (Vol. 1). Lincoln.

Weidenkeller, G. H. (1924, March 13). Briefe aus Russland [Letters from Russia]. Die Welt-Post, p. 5. (In German).

Wuertz, C. (1921, December 15). Briefe aus Beideck, Russland [Letters from Beideck, Russia]. Die Welt-Post, p. 7. (In German).

Wuertz, C. (1924, March 20). Briefe aus Russland [Letters from Russia]. Die Welt-Post, p. 3. (In German).

Wuertz, A. (1925, June 11). Original Reportagen aus Russland [Original reports from Russia]. Die Welt-Post, p. 5. (In German). 